\title{
Studying the content characteristics of New Technology-Based Firms
}

\author{
Hasan Boudlaie \\ Department of Social and Behavioral Sciences, Kish International Campus, University \\ of Tehran, Tehran, Iran \\ hasanboudlaie@ut.ac.ir
}

\author{
Mohammadhosein Kenarroodi \\ $\mathrm{PhD}$ candidate, Department of Social and Behavioral Sciences, Kish International \\ Campus, University of Tehran, Tehran, Iran \\ mohamad.kenaroodi@ut.ac.ir
}

\section{Behrouz Keshavarz Nik}

M.A. in executive Management, Kish International Campus, University of Tehran, Tehran, Iran

Behrooz.nik85@gmail.com

\begin{abstract}
New technology-based firms (NTBFs) have a significant contribution to economic growth, and in particular to the promotion of innovation and job creation. For this reason, many countries are seeking to establish and grow such institutions using incentive policies. Despite their economic importance, there is no single definition of these companies and several definitions for these types of companies are tailored to the purpose of each study. As for the nature of study, it is important to produce a coherent framework of NTBFs' characteristics; therefore, the purpose of the present study is to identify the characteristics of NTBFs. For this purpose, the researches that covered the nature of this concept from 1990 to 2011 were analyzed using content analysis. In the first phase, definitions of these companies were compiled; subsequently, effective characteristics were identified to provide a clear nature of these companies. The results of this research led to the identification, confirmation and prioritization of five characteristics, i.e. newness, possessing high-technology, independence, small size in terms of employees and volume of sales, and capital funding by company founders, all of which were prioritized according to the most frequent characteristics in the studied articles. The final result of this study is to guide and streamline future research by achieving theoretical coherence in defining this concept.
\end{abstract}

Keywords. New Technology-Based Firms (NTBF), high-technology, sustainable economic growth, entrepreneurship agencies

\section{Introduction}

Evolutions and rapid changes in the international community, moving from a traditional society to the information society, as well as the change of national economies to 
the global economy all require different ways of providing the possibility of sustainable economic growth in society (Divsalar and Bozorgi, 2012). Achieving and maintaining a high rate of sustainable economic growth is directly related to the capacity of firms and other national players in a country to innovate and develop new technologies, products and industries (Rickne \& Jacobsson, 1999). Given this assumption, technological change is a key factor in explaining economic growth (Teixeira, 2012). Numerous economists attribute the slow economic growth in financial markets of developing countries to inefficient and undeveloped information and communication technology (ICT) sector and recommend systematic reforms of this sector to achieve greater and faster economic growth (Sepehrdoost and Sadri, 2017). Therefore, NTBFs are considered as an important tool for the commercialization of innovative technologies. This commercialization leads to the economic development of countries. According to the definition of NTBFs, innovative and developing small companies are based on patents produced by technological ideas and pursuit of advancing technology-based businesses. These companies emphasize their feature of intellectual property. Although NTBF is a common term in the economics and management literature and despite the considerable research focused on this concept so far, its definition remains unclear and strongly differs among authors over different times and spaces (Autio, 1997). The problem is that when one refers to these concepts, it is often not clear what NTBF exactly means. There are different concepts regarding the definition and analysis of small and new companies with high technologies, for instance, new technology-based firms (NTBFs) (Autio, 1997; Laranja \& Fontes, 1998; Fontes \& Coombs, 2001); technology-based small companies (TBSFs) (Mason \& Harrison, 1994; Dahlstrand, 1999); small and medium technology-based enterprises (SMEs) (Meyer \& Roberts, 1986; First, 1990; Klofsten \& Jones, 1996). Since the existence of different concepts of NTBFs in the literature has made it difficult to develop knowledge regarding these firms, the need is felt to achieve a coherent theoretical framework regarding the concept of NTBFs. Accordingly, the purpose of this study is to identify the content characteristics of NTBFs using content analysis research methodology. For this purpose, in the first step, the authors present valid definitions of NTBFs in the literature review section which are derived from previous studies. In the following section, the key elements regarding the definitions of NTBFs have been extracted according to the findings of the research. These definitions are examined and prioritized with respect to the significance of their references in the related literature. Since there are plenty of definitions and interpretations on the nature of NTBFs which make it problematic to have a common understanding of this phenomenon, it is necessary to explore the most prominent definitions and natural characteristics of this phenomenon for the purpose of theoretical unity. Having this in mind, the main question of this research is, "What are the most important content characteristics NTBFs based on the data and findings of valid and scientific literature published in this area?"

\section{Theoretical Foundations}

According to Cooper (1971), an NTBF is a firm which is focused on research and development with a major emphasis on exploiting technical knowledge. A few years later, Little (1977) defined NTBF as an independently-owned business established for not more than 25 years and based on the exploitation of an invention or technological innovation which implies substantial technological risks. Another definition considers NTBFs as subcategories of small companies which have recently been established; their operations are independent; and for the first time they focus on the commercialization of new technologies. Butchart (1987) also defines NTBFs as small and medium-sized firms operating in high technology 
sectors. Fontes and Coombs (2001) also define NTBFs as independent young firms involved in the development and/or application of new technologies. One of the first important similarities in all examined studies on the concepts of NTBFs refers to the importance of "technology" and/or "exploitation of new technical knowledge" in this type of firms. In their empirical studies, these authors confirmed the relationship between these types of firms with "development and exploitation of advanced knowledge and high technology". The next characteristic that has been focused in the theories is the term "newness". Some researchers relate "newness" to technology (Fontes and Coombs, 2001). Some other theorists consider the "youth of firms" (Rickne \& Jacobsson, 1999). In a large number of studies, as mentioned in the definitions of Table 1, the term "new" has been used simultaneously to denote 'firms' and 'technology newness'. Another interpretation for this term which can be seen among theories suggests the emergence of "new industries" (Shearman and Burrell, 1988). Table 1 presents some definitions provided for NTBFs, some key dimensions of these definitions are categorized in the following column.

Table 1. Definitions of NTBFs

\begin{tabular}{|c|c|c|}
\hline Study - (year) & Definition & Key dimensions of definition \\
\hline Cooper (1971) & $\begin{array}{l}\text { A firm that focuses on research and } \\
\text { development and places major emphasis } \\
\text { on exploiting new technical knowledge. }\end{array}$ & $\begin{array}{l}\text { - Focus on research and } \\
\text { development } \\
\text { - Exploiting technical } \\
\text { knowledge }\end{array}$ \\
\hline Autio (1994) & $\begin{array}{l}\text { The business idea of the firm is based on } \\
\text { exploiting technical knowledge and high } \\
\text { technology. }\end{array}$ & $\begin{array}{l}\text { Exploiting advanced } \\
\text { knowledge and high- } \\
\text { technology }\end{array}$ \\
\hline $\begin{array}{l}\text { Bollinger et al. } \\
(1983)\end{array}$ & $\begin{array}{l}\text { New and independent firms founded by } \\
\text { the association of a small group of } \\
\text { founders tempted to explore innovative } \\
\text { ideas. }\end{array}$ & $\begin{array}{ll}- & \text { New businesses } \\
\text { - } & \text { Independent } \\
& \text { businesses } \\
\text { - } & \text { A group of founders } \\
\text { - } & \text { Exploring technically } \\
& \text { innovative ideas } \\
\end{array}$ \\
\hline $\begin{array}{l}\text { Fontes and } \\
\text { Coombs } \\
(1996)\end{array}$ & 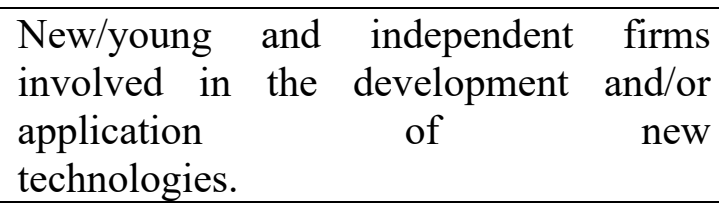 & $\begin{array}{ll}- & \text { New firms } \\
\text { - } & \text { Exploiting new } \\
& \text { technologies }\end{array}$ \\
\hline $\begin{array}{l}\text { Shearman and } \\
\text { Burrell (1988) }\end{array}$ & $\begin{array}{l}\text { New independent firms that develop new } \\
\text { industries. }\end{array}$ & $\begin{array}{ll}\text { - } & \text { New } \\
\text { - } & \text { Independent } \\
\text { - } & \text { Forming } \\
& \text { industries }\end{array}$ \\
\hline $\begin{array}{l}\text { Coeurderoy and } \\
\text { Murray (2008) }\end{array}$ & $\begin{array}{l}\text { New and independent firms based on } \\
\text { high-technologies which are formed } \\
\text { within less than } 10 \text { years. }\end{array}$ & $\begin{array}{ll}- & \text { High-tech } \\
- & \text { New } \\
- & \text { Independent } \\
\end{array}$ \\
\hline $\begin{array}{l}\text { Candi and } \\
\text { Saemundsson } \\
(2008)\end{array}$ & $\begin{array}{l}\text { New independent firms that develop new } \\
\text { products and services based on the } \\
\text { technical } \\
\text { knowledge of founders. }\end{array}$ & $\begin{array}{ll}\text { - } & \text { New and independent } \\
\text { - } & \text { Presenting new } \\
\text { services } \\
\text { - } \\
\text { Dependent on the } \\
\text { technical knowledge } \\
\text { of the founder }\end{array}$ \\
\hline
\end{tabular}




\begin{tabular}{|c|c|c|}
\hline $\begin{array}{l}\text { Candi and } \\
\text { Saemundsson } \\
(2011)\end{array}$ & $\begin{array}{l}\text { New business entities that develop new } \\
\text { offerings based on the knowledge and } \\
\text { skills embodied in engineering and the } \\
\text { natural sciences. }\end{array}$ & $\begin{array}{ll}- & \text { New } \\
& \text { generation }\end{array}$ \\
\hline $\begin{array}{l}\text { Maine et al. } \\
(2010)\end{array}$ & $\begin{array}{l}\text { Small, young, and newly-found firms } \\
\text { operating in research and development } \\
\text { (R\&D) intensive sectors. }\end{array}$ & $\begin{array}{ll}\text { - } & \text { New } \\
\text { - } & \text { Young/ newly-found } \\
\text { - } & \text { Research and } \\
& \text { development (R\&D) } \\
\end{array}$ \\
\hline Klofsten (1994) & $\begin{array}{l}\text { Competitive benefits derive from } \\
\text { knowledge engineering of the people } \\
\text { who work in these firms and provide } \\
\text { new products or services to the market as } \\
\text { a result. }\end{array}$ & 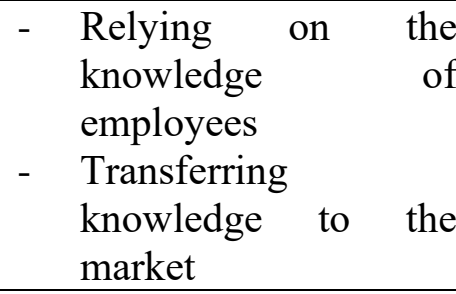 \\
\hline Butch & $\begin{array}{l}\text { Small and medium-sized firms operating } \\
\text { in high technology sectors. }\end{array}$ & $\begin{array}{l}\text { - Operating in high- } \\
\text { tech sectors } \\
\text { - Small and medium- } \\
\text { sized firms }\end{array}$ \\
\hline $\begin{array}{l}\text { Oakey et } \\
(1988)\end{array}$ & $\begin{array}{l}\text { Small firms with a higher innovative } \\
\text { potential than ordinary large and small } \\
\text { firms. }\end{array}$ & $\begin{array}{ll}- & \text { Small } \\
- & \text { Innovative potential }\end{array}$ \\
\hline
\end{tabular}

Another key characteristic is the 'independence' of these firms. Hence, the capital in firms must be mainly owned by the entrepreneurial team. Another dimension regarding independence is that these firms were totally independent, i.e. they were not a part (or subsidiary) of a large firm (Bollinger, 1983). In this regard, independence means that the majority of the social capital of these firms belongs to the entrepreneurial team (Rickne and Jacobsson, 1999).

\section{Literature Review}

Over time, an interest has grown in favor of entrepreneurship institutes and NTBFs. Some analysts consider the role of these institutions to be effective in revitalizing and repairing damaged economies (Burton, 1979). The performance and value of NTBFs in the economy can be assessed by observing several variables: sales, net income and taxes, occupation, export sales, research and development (R\&D) and their role in innovation. Studies have shown that NTBFs have a significant growth rate regarding sales, net income, and taxes. In his report to the business advisory board, Morse (DATE?) compared the sales growth of three categories of well-recognized firms from 1969 to 1974 (Little, 1977). NTBFs had an annual sales growth of $42.5 \%$, firms with innovative growth had a sales growth equal to $13.2 \%$, and mature firms had a sales growth of $11.4 \%$. For example, the average of sales in 276 firms established between 1956 to 1976 were increasing continuously. New companies had $\$ 2$ million sales on average. The average of sales volume increased over each 5-year time interval, while the average of sales in older companies was equal to $\$ 61.1$ million. Similar research results showed that 77 institutions established between 1971 to 1975 were paying taxes despite only 4 years since their foundation. In 1976, for each $\$ 100$ investment in assets, these companies paid \$15 income taxes in the federal (country) level and \$5 income taxes in the state and local level (Dunkel \& Segers, 1990). NTBFs will have a significant impact on the other areas of economy due to their rapid growth. According to numerous analysts, 
perhaps the most important impact of NTBFs is 'job creation'. Birch (1979) believes that small and new firms are the most effective entrepreneurs. Using Dun and Bradstreet data (a survey of 5.6 million companies between 1969 to1976), Birch (1979) showed that businesses with 20 or less employees account for almost $60 \%$ of US occupation; and small entrepreneurs have created almost $50 \%$ of new job opportunities, while large firms created less than $15 \%$ of job opportunities. Reviewing companies, the institute of American Electronics claimed in its report that new businesses have quick sales and higher employment growth rates in comparison to older firms (Birch, 1979). Another characteristic of NTBFs is the export sales and costs of research and development (R\&D). The studies of American Electronics institute, which were previously mentioned (77 firms established between 1971 to 1975), showed that for every $\$ 100$ of investment in net assets, these firms received $\$ 70$ for export sales and spent $\$ 33$ for R\&D costs. Small institutions (i.e. less than 1000 personnel) accounted for only $5 \%$ of research and development costs in USA, while in large organizations (i.e. more than 5,000 personnel) the number is equal to $85 \%$ (Edward, 1980). Many scholars have focused on the role of NTBFs in encouraging innovation. Most of these efforts are aimed at knowing the values and characteristics of new products and processes that are developed by these organizations. Utterback \& Abernathy (1976) used the data of Myers and Marquis (DATE 1969?) to describe the nature of innovation in small firms (most of the firms in this study were small). The firms in this sample were classified into stages of I, II, and III based on the development and evolution pattern. The institutions in stage I are at the start of their evolutionary process and are basically responding to market needs with high-performance products. The production process in these institutions is variable and unstructured. The institutions in stage II have a structured production process; technological opportunities stimulate their innovations and initiatives; and their initial strategy is to increase sales. Stage III involves the institutions whose production process is highly structured and systematic; the stimulus for innovation in these institutions is the factors directly related to the product with a tendency to reduce costs. NTBFs (the characteristics of which are newly-founded and fastgrowing) are similar to the institutions in stage I. The reason which proves this claim is that the data have shown the firms of stage I to be the small ones and the firms of stages II and III to be the large ones. Stage I innovations are at the product level rather than the process level, so innovation does not make much difference in the present technology process. Businesses in stage I consider product innovation to be a competitive strategy (Jamea et al., 1976).

\section{Research Methodology}

The ultimate purpose of this study is to achieve a theoretical coherence about the nature and the essence of NTBFs. This important matter is conducted through a content analysis of theoretical and research definitions of this concept which are published in the related literature and are validated. Therefore, as for the purpose, the current research is considered descriptive developmental because it intends to present a categorization based on the literature review, extension of literature review, and knowledge enhancement. A suitable research strategy for this purpose is a qualitative research strategy. A qualitative content analysis method has been used in this study. Among the definitions of content analysis, it seems that the definition given by Bernard Berelson (1952) is a more comprehensive one since researchers are still citing it over these years. According to Berelson (1952), "content analysis is a research technique for the objective, systematic, and quantitative description of manifest content of communications". Content analysis focuses on scientific and quantitative study of materials and qualitative data which assigns numerical values to a context based on valid measurement rules through a systematic and repeatable approach (Khanifar \& Zarvandi, 
2010). The current research focuses on micro-analysis and the frequency of data and. Next, a quantitative analysis is conducted for the qualitative data. Since data analysis in a qualitative research begins immediately after the beginning of data collection process, data collection and analysis of the current study were done simultaneously. In this research, a content analysis method has been used for the analysis of qualitative data. As for implementation of content analysis, the first step is to determine the question(s) for which the researcher intends to find answers, as well as the hypotheses which are to be tested. After defining and determining the research problem or hypothesis, the researcher must identify and define the communication sources that are directly related to the research problem. For this purpose, once the research question was determined, a set of documents or messages which may contribute to finding answers for the study questions were defined, identified and collected. Accordingly, the information derived from articles on NTBFs published during 1990 to 2011 was collected as units of analysis. The units of analysis were examined and those sections related to definitions were distinguished and presented in Table 1. In this study, the units of analysis are those articles that addresses the concept of technology-based firms and their characteristics. One unites of analysis were determined and definitions and characteristics of NTBFs were extracted, characteristics were analyzed and coded into five main categories including newness, possessing high-technology, independence, number of employees, and human capital. Then, the frequency of each code was counted. Finally, codes were evaluated and ranked according to their most common repetitions in the articles. The method for analysis of data and information obtained in the study was a descriptive statistics method, in which the frequency and repetition of codes (i.e. characteristics of the firms) was first determined and then an analysis of the results was conducted. The main research question is as follows:

A quantitative survey was conducted to find research examples regarding the characteristics of NTBFs. To do so, the related articles in the economics and management journals were searched and collected. This search was conducted according to Elsevier's Scopus, Emerald and Springe Link databases due to their ease of access and availability of management and economics articles. In this search, the selection criterion involved the term "NTBFs" which was typed in the box of "article title, abstract, key words"; no data limit was applied to the articles and magazines. The results of this search consist 142 articles published between 1990 to 2011. At the screening stage, the research samples were selected after reviewing these articles in order to identify and select the relevant ones. Since some articles did not contain any definition or key characteristics of NTBFs, these articles were omitted from the analysis. Eventually, 75 articles were prepared as the research sample in order to be analyzed. In the present research, the intellectual field of innovation and technology innovation consists of 10 journals and a total of 22 articles. The intellectual field of entrepreneurship and business management includes 20 journals and 33 articles, and intellectual field of technology consists of 9 journals and 20 articles. The three journals of Research Policy (RP), Technovation, and the International Small Business, respectively, have been used more than the other journals. In terms of study subject, these journals include intellectual fields of innovation, innovation in technology, entrepreneurship management, business management, and technology management. In total, the articles were derived from Elsevier ( 7 magazines), Emerald (5 magazines), and Springe (6 magazines). Figure 1 shows the frequency percentages of research works which examined the characteristics between 1990 to 2011 and were available to study authors. 


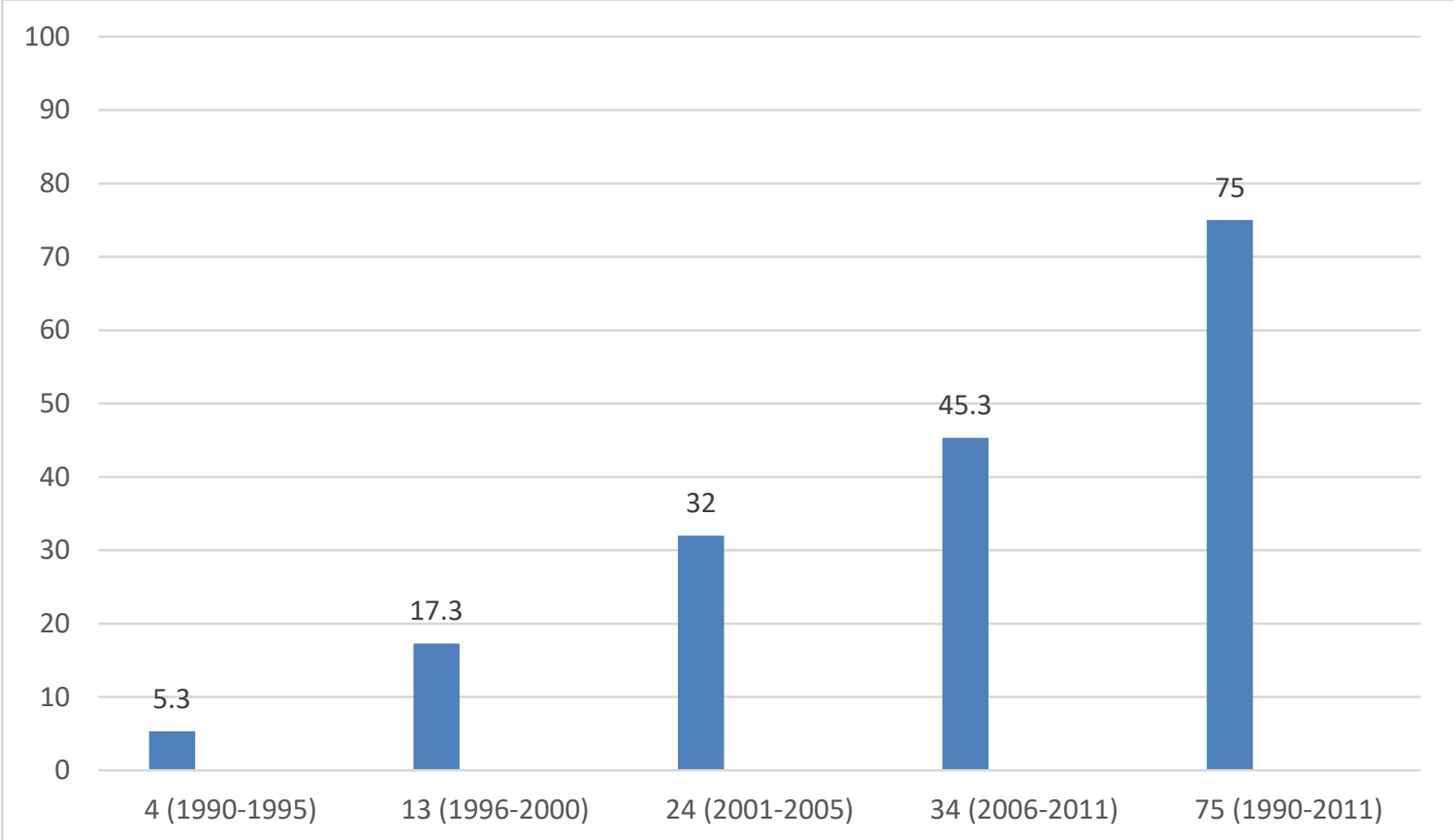

Figure 1. Frequency percentage of research articles which analyzed the concept of NTBFs between 1990 to 2011

As shown in Figure 1, the highest frequency percentage among the articles belongs to the five-year interval of 2006-2011 and the lowest frequency percentage belongs to the five-year interval of 1990-1995. Therefore, the authors observed an increasing trend in the publication of NTBFs-related articles in recent years. Hence, the study field of NTBFs is increasingly expanding. This fact, in turn, intensifies the importance of NTBFs' concept which is being studied in the present research.

\section{Analysis of the findings}

The existing literature studying the backgrounds of NTBFs have identified six characteristics in order to give a definition of this concept. In the following part, each of these characteristics are defined and prioritized according to their frequency in the studied articles. The six main dimensions of firms' characteristics extracted from the reviewed articles are described in order of importance and in terms of their frequency in these articles.

4.1. Newness (young firms)

Investigations show that the term "newness" is an important dimension regarding NTBFs' definition which refers to firms' founding dates. This dimension is mentioned in most of the research articles. Many researchers have associated the concept of NTBFs with start-up businesses (Lynskey, 2004; Colombo \& Grilli, 2011; SPLONEG? et al., 2005; Fukugawa, 2006; Colombo et al, 2010; Westvenol?, 2009; Gao et al., 2010; Piva et al., 2011). Figure 2 shows the frequency percentage in the reviewed articles which examined the dimension of "newness" when defining the characteristics of NTBFs. As can be seen in Figure 2, the first group and about half of the studied articles belonging to time interval of 1990 to 1995 define NTBFs as "new firms that are one to ten years old". This definition was confirmed in $76 \%$ of reviewed articles published between 1996 to 2000. In the two intervals of 2001-2005 and 2006-2011, this definition was confirmed in 50\% of the studied articles. In general, according to the review of 75 articles published between 1990 to 2011, the statistics approve that $54.7 \%$ of these articles define NTBFs as young firms founded between one to ten years ago. 


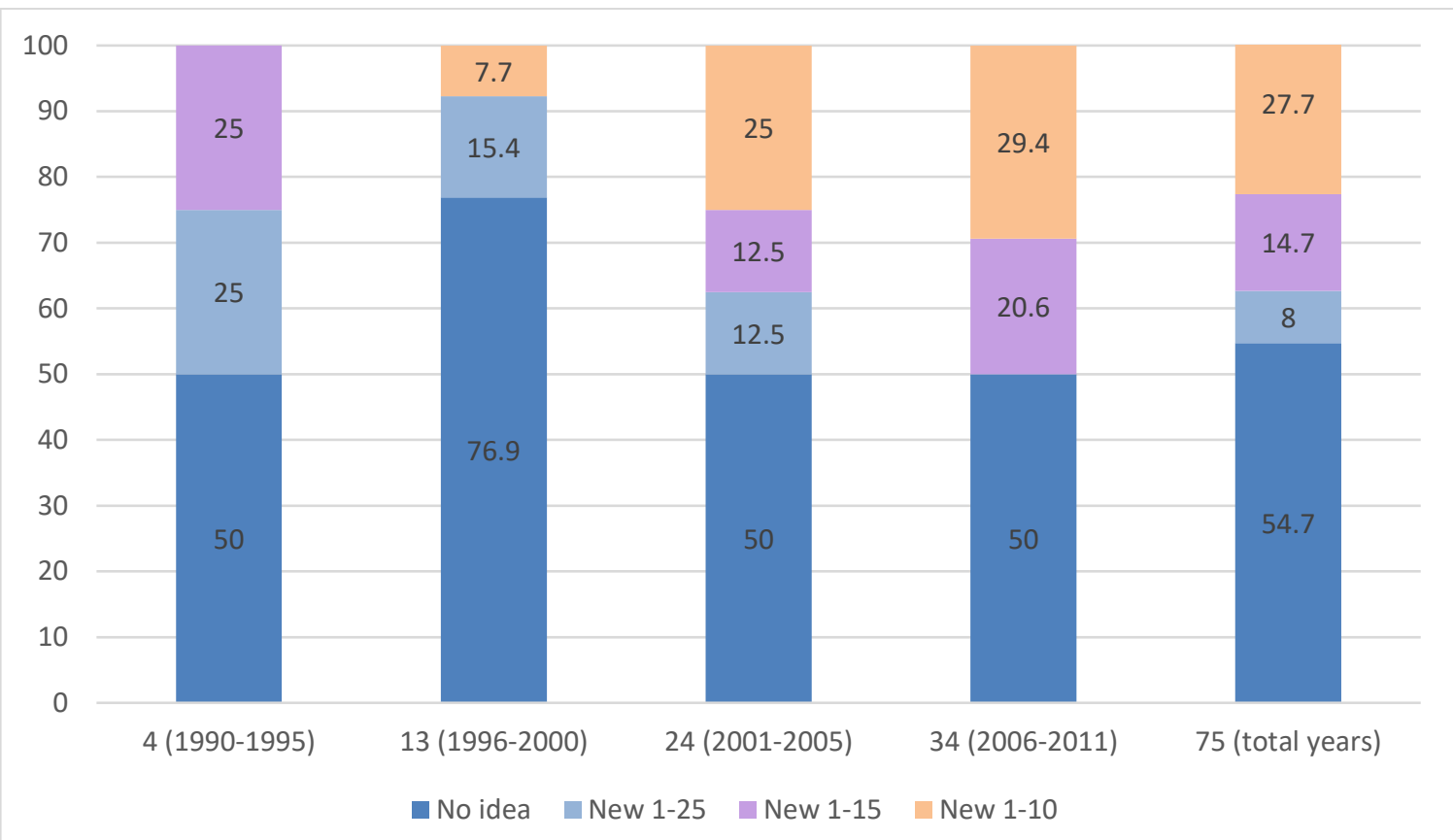

Figure 2. Frequency distribution of research articles regarding the dimension of "newness" between 1990 to 2011

The second group of studies (Hogan \& Hutson, 2005, 2006; Colombo et al., 2006; Colombo \& Grilli, 2005, 2006 ,2007, 2010; Bertoni et al., 2010, 2011; Ganotakis \& Love, 2011) which based their definitions on the recommendation of Little (1997), have defined NTBFs as businesses that do not age more than 25 years. As can be seen in Figure 2, the number of articles defining 'firms with a foundation period of 1 to 25 years' are increasing over the four reviewed time intervals. This value raised to $7.7 \%$ in between 1996 to 2000 and to $29.4 \%$ between 2006 to 2011 . In total, $27.70 \%$ of all reviewed research articles published between 1990 to 2011 have defined NTBFs as firms with a foundation age of 1 to 25 years. A third group of the studied articles defined NTBFs as firms of 1 to 15 years old. During time interval of 1990 to 1995, the number of articles that described 'foundation age of NTBFs to be between 1 to 15 years' are more than any other interval; however, this trend decreases in the subsequent intervals. This number has dropped by $15.4 \%$ and $12.5 \%$ during time intervals of 1996 to 2000 and 2001 to 2005, respectively. The total number of articles that define NTBFs as 'firms with a foundation age of 1 to 15 years' account for only $8 \%$ of the total surveyed articles between 1990 to 2011. In short, analysis of the findings shows that many articles considered a period of 1 to 10 years to determine the "newness" dimension of NTBFs, i.e. NTBFs are often considered to be new business start-ups.

\section{Possessing high-technology}

Some scholars focus on the 'exploitation of new technical knowledge' (Cooper, 1971) and the 'diffusion of new technologies' (Autio \& Lumme, 1998; Autio \& Parhankangas, 1998; Autio \& Yli-Renko, 1998) when defining NTBFs. They argue that the dynamics of NTBFs are directly linked to technology (Fontes and Coombs, 2001). Some researchers describe a technology-based firm as a company whose growth and survival depends on technology. However, this view does not indicate that technology must necessarily be new; rather, the firm's dependence on technology is the key factor (Dahlstrand, 2007). Some authors have used the concept of "high-technology" to reflect the notion of 'technological newness' in their definitions. An analysis of the definitions confirms the 
growing relationship between NTBFs and 'high-tech industry sectors'. Almost three quarters of definitions have identified 'high-technology' as one of the key dimensions of NTBFs.

Data presented in Figure 3 illustrates the frequency percentage of research articles that considered 'high-technology' to be a characteristic of NTBFs. As shown in Figure 3, 'hightechnology' is increasingly used as a characteristic of NTBFs. During the time interval of 1990 to 1995, none of the articles considered 'high-technology' to be one of the characteristics of NTBFs. However, the reviews on articles published between 2006 to 2011 have shown that $73 \%$ of articles consider 'high-technology' to be a characteristic of NTBFs. In total, the number of articles which define 'high-technology' as a characteristic of NTBFs has increased during the years 1990 to 2011 .

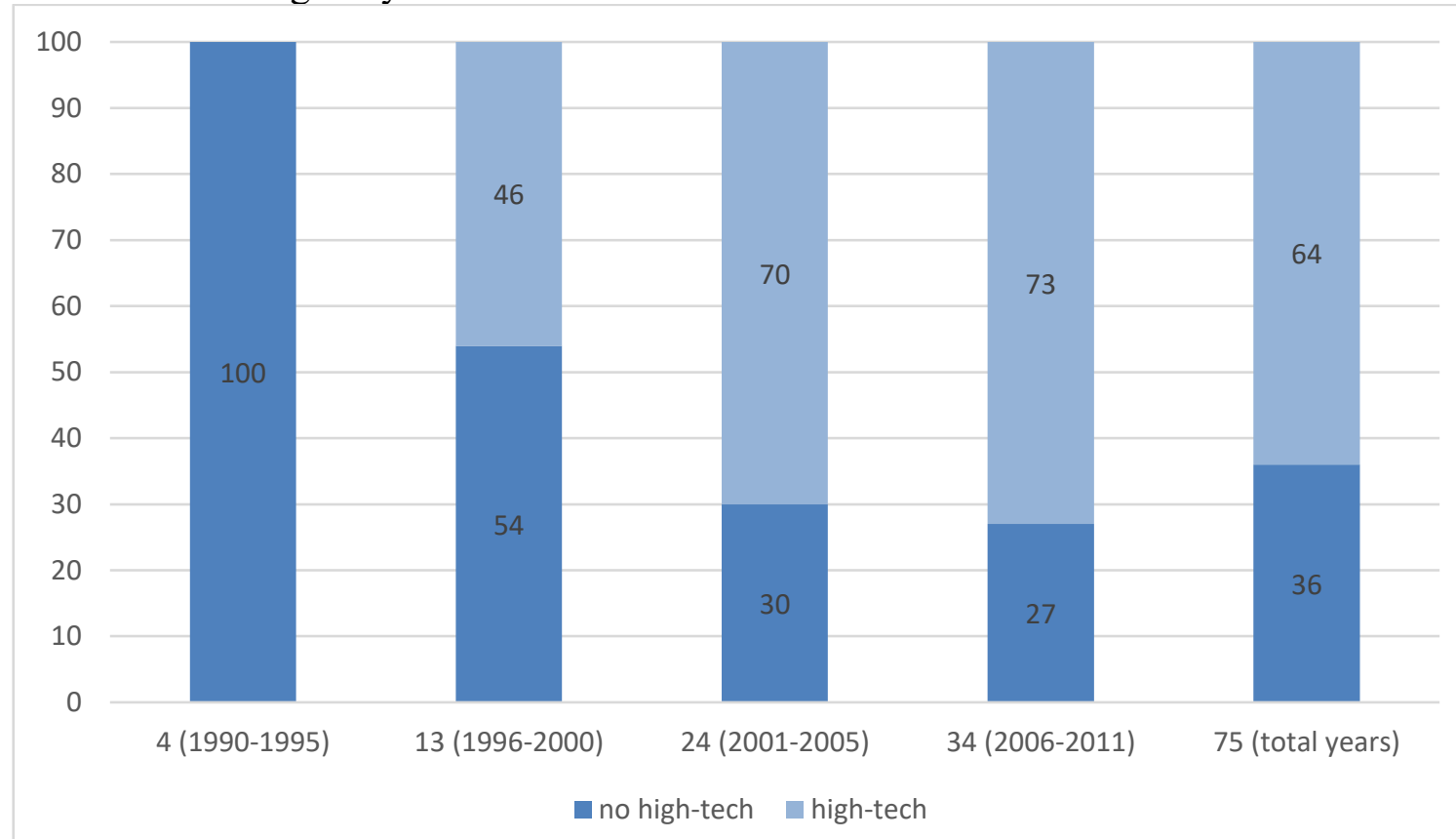

Figure 3. Distribution (\%) of articles regarding the dimension of 'high-technology', 19902011

NTBFs are important not only for the introduction of new technologies and industries, but also for the acquisition, transformation and diffusion of technology, i.e. authors identified NTBFs not only in the new sectors but also in the old ones (Laranja \& Fontes, 1998). This dimension can be referred to as a less important one in these definitions, but since it is not explicitly mentioned in the articles reviewed in the current study, we would not mention is as a distinct dimension.

\section{Independence of firms}

The Bolton Committee (1971) defines small firms as independent social and economic units, i.e. they are not a part of a larger enterprise in which managers have external control over their decisions (Stanworth \& Curran, 1976). According to Little's (1997) definition of NTBFs as independent business, it should be noted that NTBFs do not belong to a larger enterprise since Little (1997) explicitly recognizes independence as a characteristic of NTBFs. The independence criterion is described as an essential dimension in 44 of the 75 articles examined in the current study data. Meantime, independence in NTBFs is defined by two dimensions: (1) The first dimension is the independence of a firm as a separate one which does not belong to a group and is not a subsidiary of multi-national and larger firms (Fontes and Coombs, 1995, 2001; Igel and Islam, 2001; Colombo \& Piva, 2008; Colombo et al., 
2010; Brinckmann et al., 2011; Ganotakis \& Love, 2011); (2) The second dimension refers to the capital structure in this type of firms. In NTBFs, the majority of the capital structure belongs to the founding team (Brinckmann et al., 2011; Ganotakis \& Love, 2011; Colombo \& Piva, 2008; Colombo et al., 2010).

Figure 4 presents the number of research articles that examined the dimension of 'independence' when defining the characteristics of NTBFs. As shown in Figure 4, 34.7\% of all reviewed articles believed that 'independence' criterion is one of the characteristics of NTBFs. Although this number has decreased from $46.2 \%$ in the first reviewed interval of 1996-2000 to $17.6 \%$ in the interval of 2011-2006; in contrast, the 'independence' dimension in NTBFs is centered in the criterion known as "the belonging of capital majority to the founder" which have increased from 7.7\% among articles published during the 1996-2000 period to $32.4 \%$ among articles published during the 2006-2011 period. In the meanwhile, the number of articles that defined NTBFs as dependent firms have decreased from $72 \%$ during the 1990-1995 period (the largest number of articles in that period) to $46 \%$ during the 19962000 period and to $20 \%$ during the $2000-2005$ period. Interestingly, this trend has increased to $50 \%$ of articles during the 2005-2012 period. The total number of articles throughout all periods which defined NTBFs as dependent firms is equal to $41.3 \%$. The highest frequency in terms of the three criteria considered for 'independence' dimension is related to 'dependence' dimension in these firms. In general, as can be seen in Figure 4, the number of articles which refer to independence (regarding both dimensions) is higher than those articles which consider NTBFs as dependent firms.

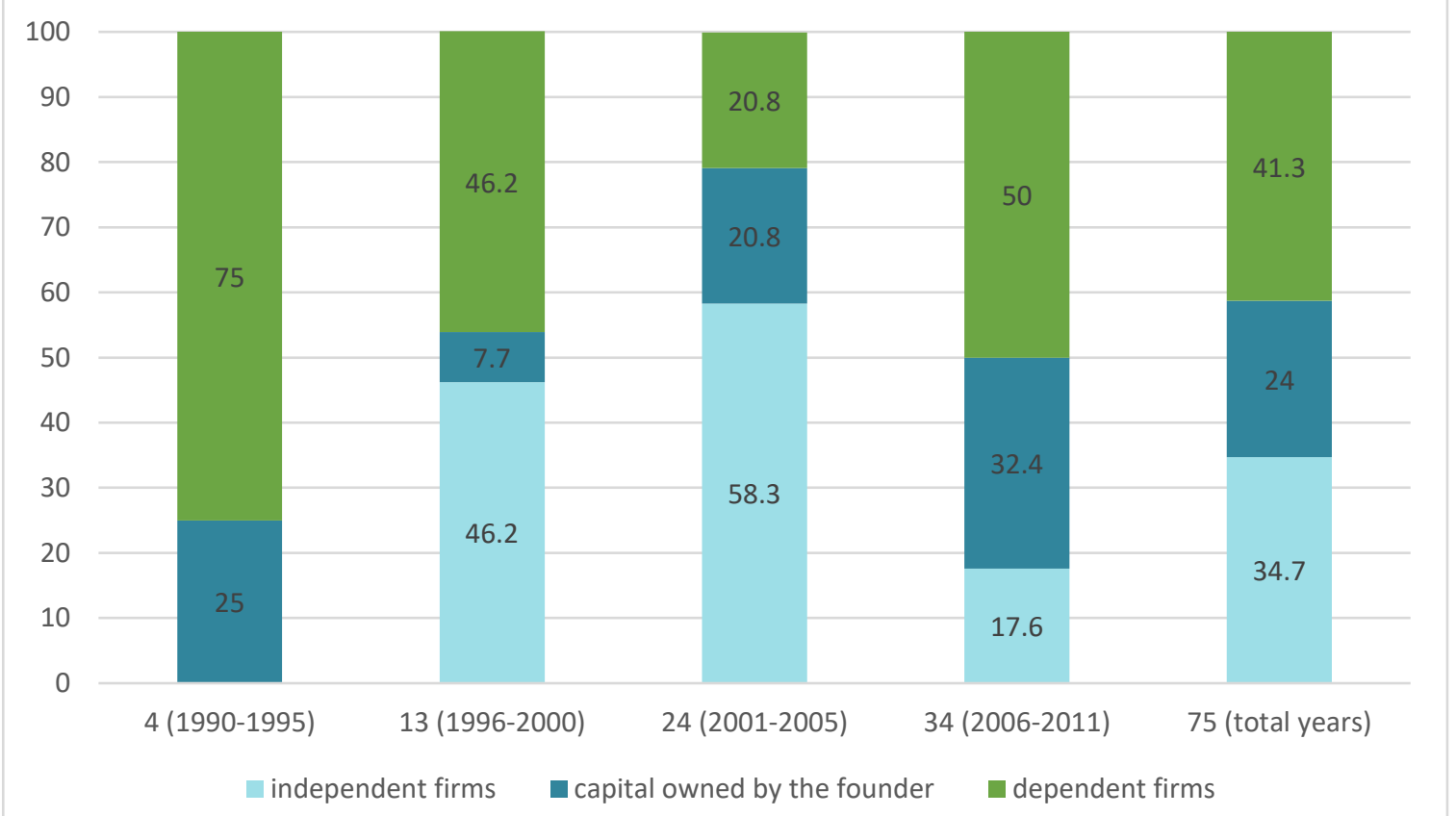

Figure 4. Distribution (\%) of articles regarding the dimension of 'independence', 1990-2011

\section{Size of the firm}

NTBFs are often defined as small and medium-sized firms (Butchart, 1987) and firms that are small in the beginning (Maine et al., 2010). Storey and Tether (1998) describe NTBFs as "new and small technology-based firms".

Figure 5 shows the number of research articles that examined the dimension of "size" in defining the characteristics of NTBFs. A total of 50 articles, i.e. $54.7 \%$ of the total reviewed articles, measured the size of NTBFs according to the number of employees. 
Existing empirical studies include a sample of firms that are mostly small in size. As shown in Figure 5, 49.3\% of all reviewed studies during the period of 1990 to 2011 have mentioned the size of NTBFs to be 'small'. Meanwhile, only two studies assume NTBFs to be of 'medium' size and another two considered a 'large' size for these firms. The number of articles that did not mention dimension of 'size' in their studies increased over time. They accounted for 50\% of total articles in the period of 1990 to 1995; however, their total number was equal to the lowest value, i.e. zero, in the second period (1996-2000). Then, an increase was observed during the 2001-2006 period which was equal to $43.7 \%$, and $64.7 \%$ during the most recent period of 2006-2011. Overal, the total number of articles that have not mentioned 'size' dimension in their examinations over the entire studied period (1990-1991) is equal to $45.3 \%$ of the total number of articles. It can be concluded that 'size' is not very important in defining the characteristics of NTBFs in terms of the frequency of being mentioned throughout articles.

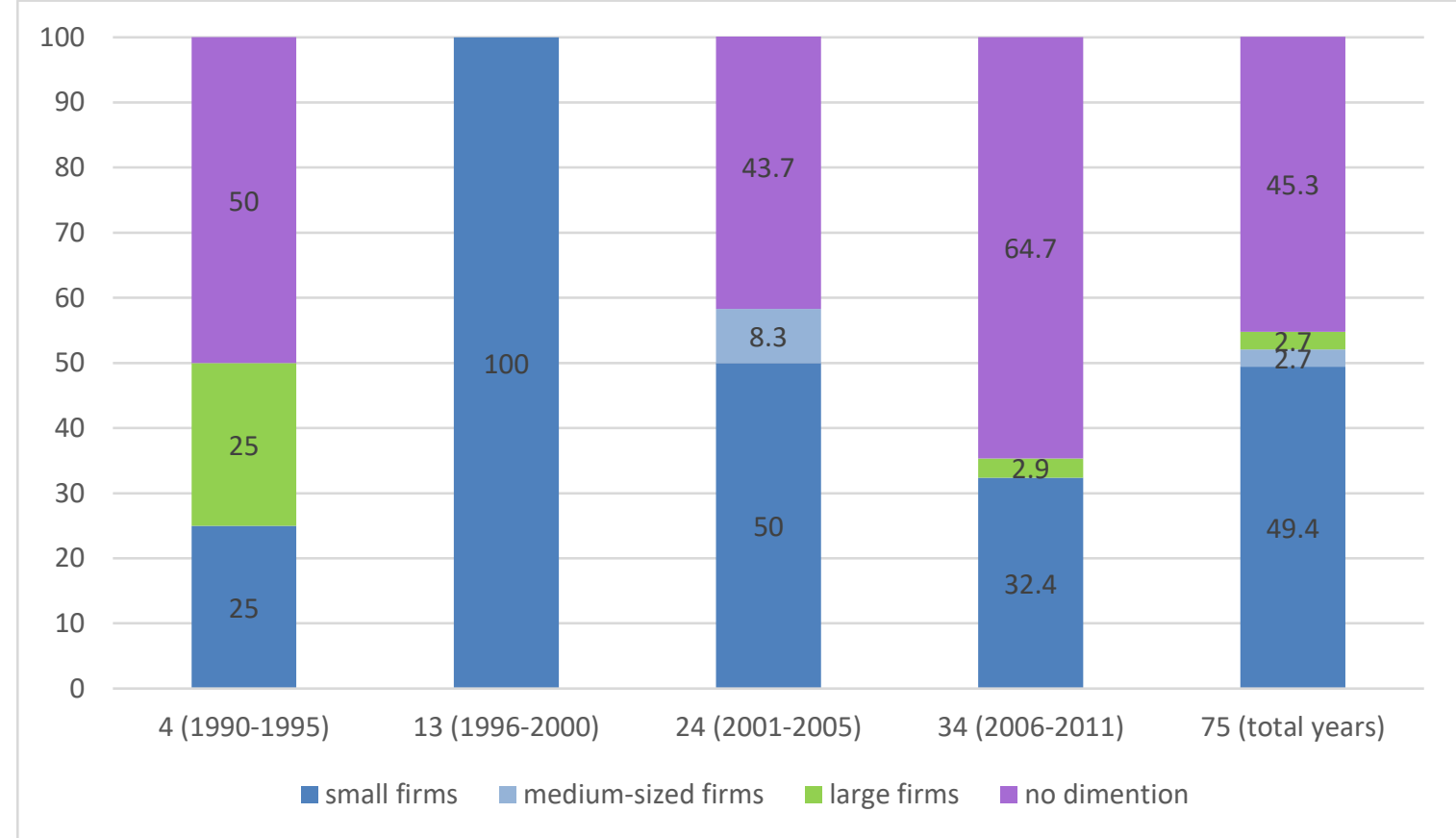

Figure 5. Distribution (\%) of articles regarding the dimension of 'size', 1990-2011

According to the classification of small and medium firms by EU, these firms have a turnover of no more than $€ 50$ million/or an annual balance sheet no more than $€ 43$ million. Figure 6 displays the number of articles that have examined the 'size' dimension in terms of annual turnover while defining the characteristics of NTBFs. Only a marginal portion of records in NTBFs consider 'turnover' to be the same as the 'size' dimension. Among the articles focused in this study, a number of 7 articles have addressed this issue throughout the entire period of 1990 to 2011 , accounting for $9.3 \%$ of the total articles. Therefore, with regard to the frequency of being mentioned in reviewed articles, the dimension of 'size' can still be defined based on the number of employees. 


\section{(11) TECHNIUM}

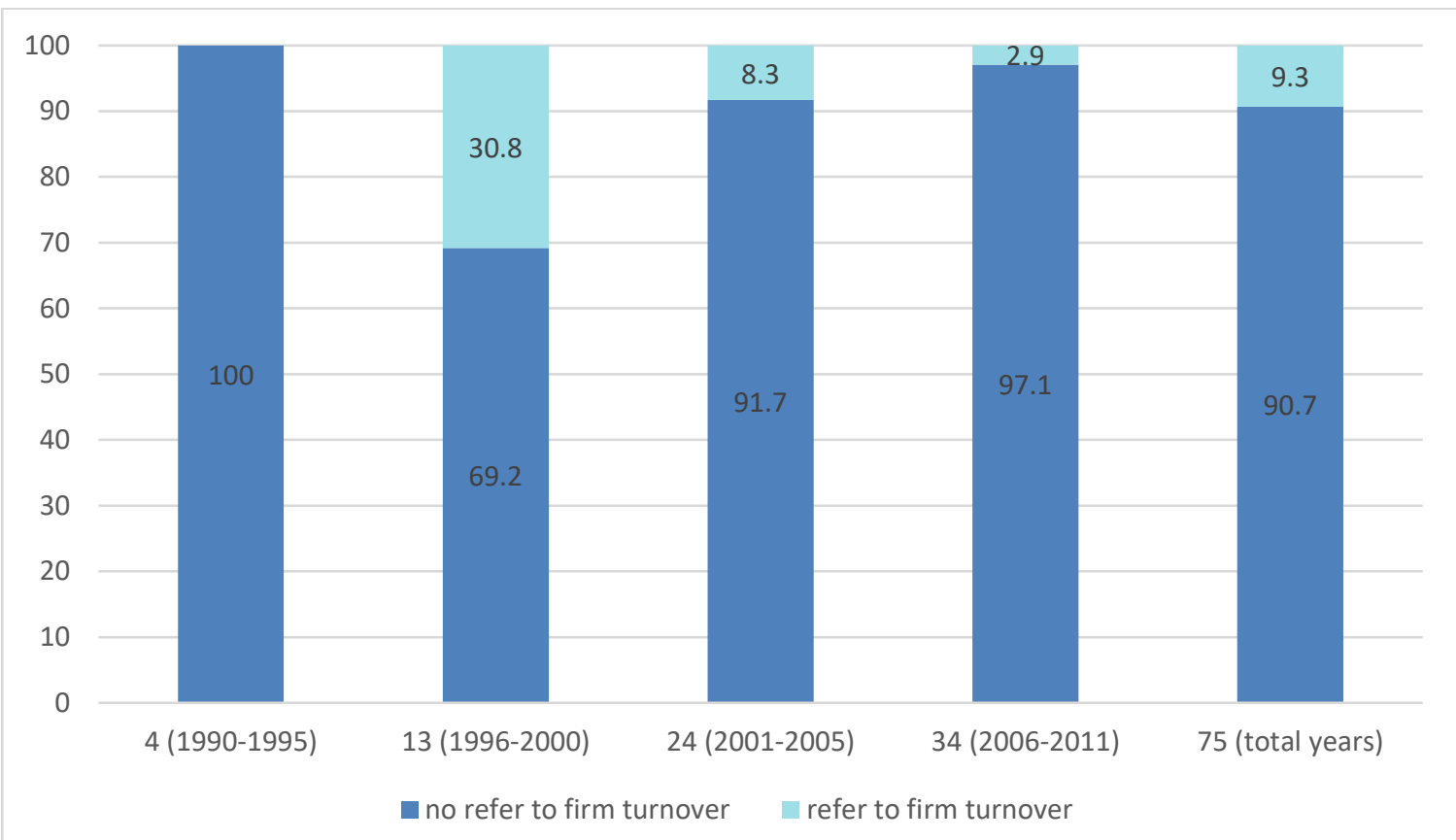

Figure 6. Distribution (\%) of articles regarding the dimension of 'size' (turnover), 1990-2011

\section{Characteristics of founders (human capital)}

The human capital of founders has been recognized as an early asset to gain competitive advantages (Cooper \& Baruno, 1977; Colombo \& Grilli, 2006, 2010). It is believed that only the individuals with a technical competence at the highest academic level are capable of establishing NTBFs with the ability to exploit technology and present innovative products to the market (Ganotakis, 2010). The strategic direction of NTBFs should be determined by anticipating the future needs of the market environment which will come into existence not only by identifying technological trends but also by combining and integrating knowledge in specific fields (e.g. marketing, strategic management, and/or property rights) among key individuals across a firm. Many authors believe that human capital and their capabilities are more important than technological knowledge for NTBFs to succeed in business (Colombo \& Delmastro, 2002; Chapman \& Oakey, 2003; Coster \& Butler, 2005; Roskos \& Klandt, 2007; Brinckmann et al., 2011). Knowledge and experience of the owners enable them to successfully adapt to changes in technology and market trends (Colombo \& Grilli, 2006, 2011; Ganotakis, 2010; Taheri \& Geenhuizen, 2011). The human perspective includes various dimensions such as ability, experience, trained skills, attitudes, and behaviors as well as characteristics such as individual motivations, ambition and leadership (Mayo, 2001; O'Regan \& Ghobadian, 2006). In their study, Colombo and Grilli (2004) define "human capital of founders" as the technical, organizational and managerial skills of each individual founder and their joint use in newly-founded firms so as to achieve synergistic gains. They are of the opinion that founders' relationships with potential customers, suppliers, business partners, and financial providers - usually referred to as social or relational capital in the related literature- is also a part of human capital (Colombo \& Grilli, 2004). Some studies (Colombo \& Grilli, 2005; Bianchi et al., 2011; Brinckmann et al., 2011) emphasize the characteristics related to a high level of education and knowledge linked with founders. From an operational perspective regarding the concept of NTBFs, although many authors have confirmed and studied the relationship between a firm's technological foundations and the scientific background of its founders (Igel \& Islam, 2001), the capabilities 
and characteristics of founding team are rarely recorded in the proposed definitions. The number of articles that have examined the "characteristics of founders" (human capital) dimension are presented in Figure 7. According to the data in Figure 7, only 9 research articles (12\% of the total) focused on the dimension of "human capital" when defining the characteristics of NTBFs.

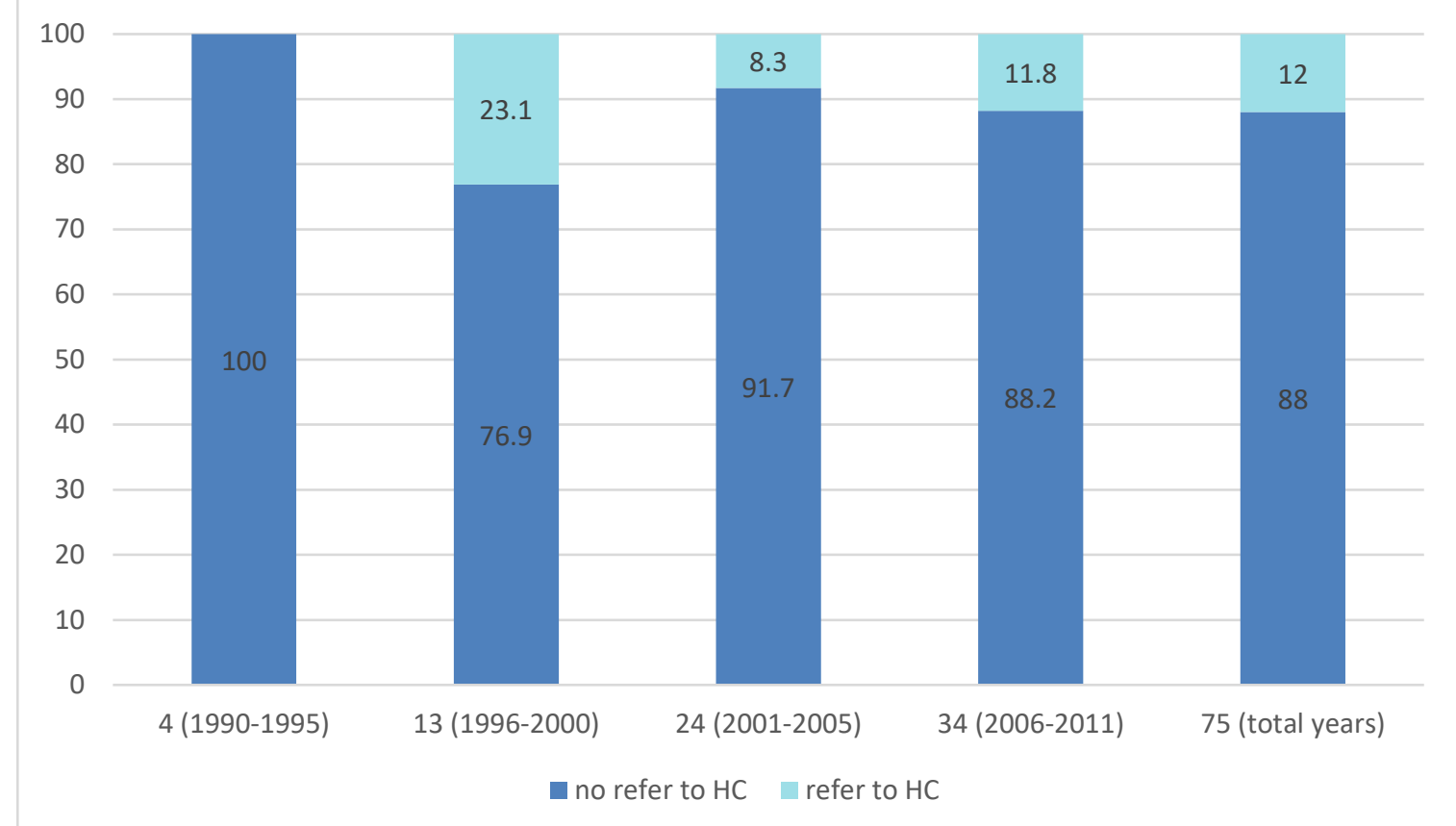

Figure 7. Distribution (\%) of articles regarding the dimension of 'human capital', 1990-2011 According to the findings of the present bibliometric research, the criteria associated with the study concepts are as follows:

1) Newness of technology and the emergence of new industry, according to which NTBFs are firms that focus on exploitation of new technical knowledge as well as advanced knowledge and high technology, and on the development and diffusion of new technologies;

2) Youth of firms which alludes to their newness. According to these definitions, NTBFs include firms that have been founded in less than 10 years ago;

3) The size of firms that are defined with respect to two dimensions of 'the number of employees' and 'annual sales' in the reviewed articles. As a result, only the firms are defined as NTBFs that are small in terms of fewer number of employees as well as annual sales and turnover no more than $€ 50$ million/or an annual balance sheet no more than $€ 43$ million a year;

4. Independence of firms which reflects the fact that in NTBFs, the majority of the capital belongs to the founding team, these firms are not subsidiary of larger multi-national firms and are managed independently;

5. Human capital of the founding team which refers to the characteristic of 'high level of education and knowledge' among founders.

\section{Conclusion}

In line with the importance of NTBFs in knowledge-based growth and economic development, the authors sought to provide a coherent definition of the concept of NTBFs in this study. To do so, the contents of most significant published articles between 1990 to 2011 in the field of NTBFs were analyzed. Studying the articles published between 1990 to 2011 on NTBFs indicated that the research field related to NTBFs is expanding. The number of 
articles surveying NTBF concept has increased from 5.3\% in the 1990-1995 period to $45.3 \%$ in the 2006-2012 period which indicates the significance and attention considered for this area of research. This present study examines the literature on NTBFs so as to find the most relevant dimensions used to define the concept of NTBFs in the articles published between 1990 to 2011. After extracting the characteristics with the help of a bibliometric measurement of articles, the most significant dimensions referred in these articles were categorized on the basis of frequency and in order of importance. Of the six characteristics, i.e. newness (firms between 1 to 10 years of age); possessing high technology; independence; small-sized firms in terms of employees; capital funding by founders; small-sized firms in terms of sales volume and turnover, the two dimensions of 'newness' and 'possessing high technology' had the most frequency among the study dimensions, $89 \%$ and $64 \%$, respectively. The dimension of 'human capital', being mentioned in $12 \%$ of reviewed articles, was the least frequent dimension.

In terms of criteria associated with the concept of NTBFs, these firms are young and small firms that operate independently and focus on the development and diffusion of new technologies based on the human capital of their founding team. The final study findings are summarized in Table 2 with a reference to the dimensions and characteristics of NTBFs. Dimensions are mentioned in order of priority throughout the reviewed articles published during the time interval of 1990 to 2011.

Table 2. Different dimensions of NTBFs concept based on the number of articles

\begin{tabular}{|l|l|l|l|l|l|l|l|l|}
\hline $\begin{array}{l}\text { NTBFs } \\
\text { dimensions }\end{array}$ & $\begin{array}{l}\text { Type of the } \\
\text { dimension }\end{array}$ & \multicolumn{2}{|l|}{$\begin{array}{l}\text { 1996-2000 } \\
(\%)\end{array}$} & \multicolumn{2}{l}{$\begin{array}{l}2001-2005 \\
(\%)\end{array}$} & \multicolumn{2}{l}{$\begin{array}{l}2006-2011 \\
(\%)\end{array}$} & \multicolumn{2}{|l|}{$\begin{array}{l}\text { All periods } \\
\text { (number of } \\
\text { articles) }\end{array}$} \\
\hline Newness & & 13 & $100 \%$ & 21 & $87.5 \%$ & 27 & $79.4 \%$ & 64 \\
\hline $\begin{array}{l}\text { Possessing } \\
\text { high-tech }\end{array}$ & & 6 & $46.5 \%$ & 17 & $70.8 \%$ & 25 & $73.5 \%$ & 48 \\
\hline Independence & & 7 & $53.9 \%$ & 19 & $79.2 \%$ & 17 & $50 \%$ & 44 \\
\hline Size & $\begin{array}{l}\text { Number of } \\
\text { employees }\end{array}$ & 13 & $100 \%$ & 14 & $58.3 \%$ & 12 & $35.3 \%$ & 41 \\
\cline { 2 - 10 } & $\begin{array}{l}\text { Sales volume } \\
\text { (annual } \\
\text { turnover) }\end{array}$ & 4 & $30.8 \%$ & 2 & $8.3 \%$ & 1 & $2.9 \%$ & 7 \\
\hline $\begin{array}{l}\text { Human } \\
\text { Capital }\end{array}$ & & 3 & $23.1 \%$ & 2 & $8.3 \%$ & 4 & $11.8 \%$ & 9 \\
\hline
\end{tabular}

As can be observed in Table 2, each dimension is presented in order of frequency in surveyed articles. In the first 5-year period (1996-2000), the dimensions of 'newness' and 'number of employees' held the most frequency among all dimensions, being mentioned in 13 reviewed articles. Thereafter, the dimension of 'possessing high technology' hold onto the second place in terms of frequency among the characteristics of NTBFs with a number of 6 articles. The dimension of 'human capital' is placed last in terms of frequency, being mentioned in only 3 articles. In the second 5-year period (2001-2005), the dimensions of 'newness' and 'independence' were the most frequent dimensions and 'human capital' was the least frequent one. In the third 5-year period (2006-2011), the dimensions of 'newness' and 'possessing high technology' were the most frequent dimensions and again 'human capital' was the least frequent one. 
According to the obtained results, it can be noted that based on the reviewed articles published during all time intervals of the study (1990-2011), the most important and most frequent dimensions in terms of being mentioned in articles are "newness' and 'possessing high technology', respectively. The dimension of 'human capital' which refers to the characteristics of NTBFs' founders seems to be the least frequent dimension.

Table 3. The final ranked codes in relation to the characteristics of NTBFs

\begin{tabular}{|c|c|c|c|}
\hline $\begin{array}{ll}\begin{array}{l}\text { Dimensions } \\
\text { characteristics }\end{array} & \text { of } \\
\end{array}$ & Time interval & $\begin{array}{l}\text { Frequency of articles } \\
\text { (n) }\end{array}$ & $\begin{array}{l}\text { Frequency of articles } \\
(\%)\end{array}$ \\
\hline $\begin{array}{l}\begin{array}{l}\text { Newness } \\
\text { years })\end{array}\end{array}$ & \multirow{6}{*}{$1990-2011$} & 64 & $89 \%$ \\
\hline Possessing High-tech & & 48 & $64 \%$ \\
\hline Independence & & 44 & $58 \%$ \\
\hline $\begin{array}{l}\text { Size: } \\
\text { a) number of } \\
\text { employees }\end{array}$ & & 41 & $54 \%$ \\
\hline $\begin{array}{l}\text { b) Sales volume } \\
\text { (annual turnover) }\end{array}$ & & 7 & $9 \%$ \\
\hline Human Capital & & 9 & $12 \%$ \\
\hline
\end{tabular}

The final purpose of this study was to achieve a theoretical coherence with respect to the concept of NTBFs. Through this research, the authors attempted to acquaint readers with a summary of the current research trends in this area and a background of definitions related to the concept of NTBFs. A rigorous theoretical foundation was developed for this purpose. The research is expected to streamline future research and expand the nature of knowledge in this area. In the same vein, it is recommended to other researchers to consider the following issues while investigation NTBFs: (1) What is the role of NTBFs firms in economic reinforcement and what factors and circumstances contribute to this stream?; (2) What factors are effective for the success of these firms?; (3) What NTB businesses will succeed in cultural, economic and political fields; and (4) What government policies are effective in stimulating and supporting these newly-founded firms?

\section{References}

[1] Autio E. (1994), Four types of innovators. A conceptual and empirical study of new technologybasedcompanies as innovators, Helsinki University of Technology.

[2] Autio E. (1997a), Atomistic and systemic approaches to research on new, technology-based firms: Aliterature study, Small Business Economics, Vol. 9, pp. 195-209.

[3] Autio E. (1997b), New, technology-based firms in innovation networks symplectic and generativeimpacts, Research Policy, Vol. 26, pp. 263-281.

[4] Autio E. and Lumme A. (1998), Does the innovator role affect the perceived potential for growth?Analysis of four types of new technology-based firms, Technology Analysis \& StrategicManagement, Vol. 10, N. 1, pp. 41-54.

[5] Autio E. and Parhankangas A. (1998), Employment generation potential of new, technology-basedfirms during a recessionary period: The case of Finland, Small Business Economics, Vol. 11,pp. 113-123.

[6] Autio E. and Yli-Renko H. (1998a), New, technology-based firms in small open economies - Ananalysis based on the Finnish experience, Research Policy 26, 973-987. 
[7] Bertoni F., Colombo M.G. and Croce, A. (2010), The effect of venture capital financing on thesensitivity to cash flow of firm's investments, European Financial Management, Vol. 16, N.4, pp. 528551.

[8] Bertoni F., Colombo M.G. and Grilli L. (2011), Venture capital financing and the growth of high-techstart-ups: Disentangling treatment from selection effects, Research Policy, Vol. 40, pp. 1028-1043.

[9] Bertoni F., Croce A. and D'Adda D. (2010), Venture capital investments and patenting activity ofhightech start-ups: A micro-econometric firm-level analysis, Venture Capital, Vol. 12, N. 4,pp. 307-326.

[10] Bianchi M., Chiaroni D., Chiesa V. and Frattini F. (2011), Exploring the role of human resources intechnology out-licensing: an empirical analysis of biotech new technologybased firms,Technology Analysis \& Strategic Management, Vol. 23, N. 8, pp. 825-849.

[11] Birch.D(1979). The Jab Generation Process (MIT Program Neighborhoods and Change, Cambridge,MA,1979)

[12] Bollinger L., Hope K. and Utterback J.M. (1983), A review of literature and hypotheses on newtechnology-based firms, Research Policy, Vol. 12, pp. 1-14.

[13] Brinckmann J., Salomo S. and Gemuenden H.G. (2011), Financial management competence offounding teams and growth of new technology-based firms, Entrepreneurship: Theory andPractice, Vol. 35, N. 2, pp. 217-243.

[14] BurtonH.Klein.(1979).The Slowdown in Productivity Advanes:ADynamic Explanation,in:Christopher T.Hill and JamesM. Utterback(Eds) Technological Innovation for a Dynamic Economy (Pergmon Press, New York 1979).

[15] Butchart, R.I. (1987). A new UK definition of the high technology industries, Economic Trends, Vol. 40, pp. 82-88.

[16] Candi M. and Saemundsson R. (2008), Oil in water? Explaining differences in aesthetic designemphasisin new technology-based firms, Technovation, Vol. 28, pp. 464-471.

[17] Coeurderoy R. and Murray G. (2008), Regulatory environments and the location decision: evidencefrom the early foreign market entries of new technology-based firms, Journal of InternationalBusiness Studies, Vol. 39, pp. 670-687.

[18] Colombo M.G. and Grilli L. (2006), Supporting high-tech start-ups: Lessons from Italian technologypolicy, International Entrepreneurship Management Journal, Vol. 2, pp. 189209.

[19] Colombo M.G. and Grilli L. (2007), Funding gaps? Access to bank loans by high-tech start-ups,Small Business Economics, Vol. 29, pp. 25-46.

[20] Colombo M.G. and Grilli L. (2010), On growth drivers of high-tech start-ups: Exploring the role offounders' human capital and venture capital, Journal of Business Venturing, Vol. 25, N. 6, pp.610-626.

[21] Colombo M.G. and Grilli, L. (2005a), Start-up size: The role of external financing, EconomicsLetters, Vol. 88, pp. 243-250.

[22] Colombo M.G. and Grilli, L. (2005b), Founders' human capital and the growth of new technologybasedfirms: A competence-based view, Research Policy, Vol. 34, pp. 795-816.

[23] Colombo M.G. and Piva E. (2008), Strengths and Weaknesses of Academic Startups: A ConceptualModel, IEEE Transactions on Engineering Management, Vol. 55, N. 1, pp. $37-$ 49.

[24] Colombo M.G., D'Adda D. and Piva E. (2010), The contribution of university research to the growthof academic start-ups: an empirical analysis, Journal of Technology Transfer, Vol. 35, pp.113-140. 
[25] Colombo M.G., Grilli, L. and Piva E. (2006), In search of complementary assets: The determinants ofalliance formation of high-tech start-ups, Research Policy, Vol. 35, pp. 1166-1199.

[26] Cooper A.C. (1971), The founding of technologically-Based Firms, Milwaukee: The Center forVenture Management.Cooper A.C. and Bruno A.V. (1977), "Success among high-technology firms", Business Horizons, Vol. 20, pp. 16-22.

[27] Dahlstrand A.L. (1999), Technology-based SMEs in Goteborg Region: Their origin and interactionwith Universities and large firms, Regional Studies, Vol. 33, pp. 379-389.

[28] Dahlstrand A.L. (2007), Technology-based entrepreneurship and regional development: The case ofSweden, European Business Review, Vol. 19, N. 5, pp. 373-386.

[29] Diasalar, Samaneh and Bazargi, Farshad (2012). Review of the role of entrepreneurship in economic growth and sustainable development. National Conference on Business and Business Knowledge Management, Mazandaran University, 12-1

[30] Donckels R. and Segers J.P. (1990), New technology based firms and the creation of regional growthpotential - Theoretical considerations and empirical evidence for Belgium. Small BusinessEconomics, Vol. 2, pp. 33-44.

[31] Dosi G. (1984), Technical Change and Industrial Transformation, Macmillan, London.Druilhe C. and Garnsey E. (2000), Emergence and growth of high-tech activity in Cambridge andGrenoble

[32] Edvin V .W . Zschau, C.(1978). Capital Formation Taskforceof the American Electronic Association.Statement befor the Senate Select Com $\sim \mathrm{tt} \sim$ on Small Business, February8, 1978

[33] Edward B. Robert( 1980).Getting New Ventures off Ground ,management Reoiew (june 1980).

[34] Fontes M. and Coombs R. (1996), New technology-based firm formation in a less advanced country:a learning process, International Journal of Entrepreneurial Behavior and Research, Vol. 2,pp. 82-101.

[35] Fontes M. and Coombs R. (2001), Contribution of new technology-based firms to the strengtheningof technological capabilities in intermediate economies, Research Policy, Vol. 30, pp. 79-97.

[36] Fukugawa N. (2006), Science parks in Japan and their value-added contributions to new technologybasedfirms, International Journal of Industrial Organization, Vol. 24, pp. 381400.

[37] Ganotakis P. (2010), Founders' human capital and the performance of UK new technology basedfirms, Small Business Economics, Published online: 24 December 2010.

[38] Ganotakis P. and Love J.H. (2011), R\&D, product innovation and exporting: evidence from UKNTBFs, Oxford Economic Papers, Vol. 63, pp. 279-306.

[39] Gao J., Li J., Chey Y. and Shi S. (2010), Impact of initial conditions on new venture success: Alongitudinal study of new technology-based firms, International Journal of InnovationManagement, Vol. 14, pp. 41-56.

[40] Hogan T. and Hutson E. (2005), Capital structure in new technology-based firms: Evidence from theIrish software sector, Global Finance Journal, Vol. 15, pp. 369- 387.

[41] Hogan T. and Hutson E. (2006), The relation between key events in the development phase and thefinancial structure of NTBFs in the software sector, International EntrepreneurshipManagement Journal, Vol. 2, pp. 227-243.

[42] Igel B. and Islam N. (2001), Strategies for service and market development of entrepreneurialsoftware designing firms, Technovation, Vol. 21, pp. 157-166. 
[43] Jamea M. Utterback and William J. Abernathy (1976). A Dynamic Model of PROCESS AND Product Innovation, Omega 3(1976).

[44] Khannifar, Hossein and Zarandi, Nafiseh (2010). Qualitative Research: A New Approach in Management Studies. Strategic Quarterly. No. 54, 243-256.

[45] Klofsten M. (1994), Technology-based firms: Critical aspects of their early development, Journal ofEnterprising Culture, Vol. 2, pp. 535-557.

[46] Laranja M. and Fontes M. (1998), Creative adaptation: The role of new technology based firms inPortugal, Research Policy, Vol. 26, pp. 1023-1036.

[47] Little A.D. (1977), New Technology Based Firms in the UK and the FRG, Wilton House Publications, London.Löfsten H. and Lindelöf P. (2001), Science parks in Sweden: Industrial renewal and development?,R\&D Management, Vol. 31, N. 3, pp. 309-322.

[48] Lynskey M.J. (2004), Knowledge, finance and human capital: The role of social institutionalvariables on entrepreneurship in Japan, Industry and Innovation, Vol. 11, N. 4, pp. 373-405.

[49] Maine E.M., Shapiro D.M. and Vining A.R. (2010), The role of clustering in the growth of newtechnology-based firms, Small Business Economics, Vol. 34, pp. 127-146.

[50] Meyer M. H. and Roberts E.B. (1986), New Product strategy in small technology-based firms,Management Science, Vol. 32, pp. 806-821.

[51] Oakey R., Rothwell R. and Cooper S. (1988), The Management of Innovation in High TechnologySmall Firms, Pinter, London.

[52] Piva E., Grilli L. and Rossi-Lamastra C. (2011), The creation of high-tech entrepreneurial ventures atthe local level: The role of local competences and communication infrastructures, Industry andInnovation, Vol. 18, N. 6, pp. 563-580.

[53] Rickne A. and Jacobsson S. (1999), New technology-based firms in Sweden - A study of their impacton industrial renewal, Economic Innovation New Technology, Vol. 8, pp. 197223.

[54] Sepehr Dost, Hamid and Sadri, Lily (2017). Influence of Technology and Communication on Capital Market Growth: Experimental Evidence from Tehran Stock Exchange. Quarterly Journal of Information Technology Management Studies. Dora 5, No. 19, Spring 1396, 1-28

[55] Shearman C. and Burrell G. (1988), New technology-based firms and the emergence of newindustries: Some employment implications, New Technology Work Employment, Vol. 3, N. 2, pp. 87-99.

[56] Stanworth M.J.K. and Curran J. (1976), Growth and the small firm: An alternative view, TheJournal of Management Studies, Vol. 1, pp. 95-110.

[57] Storey D.J. and Tether B.S. (1998a), New technology-based firms in the European Union: Anintroduction, Research Policy, Vol. 26, pp. 933-946.

[58] Storey D.J. and Tether B.S. (1998b), Public policy measures to support new technologybased firmsin the European Union, Research Policy, Vol. 26, pp. 1037-1057.

[59] Teixeira A.C. (2012), Technological Change, Aurora Teixeira, InTech. Croacia.West III P. and Noel T.W. (2009), "The Impact of Knowledge Resources on New VenturePerformance", Journal of Small Business Management, Vol. 47 ,N. 1, pp. 1-22. 